Annals of Plant and Soil Research 23(1): 104-107(2021)

https://doi.org/10.47815/apsr.2021.10038

\title{
Seasonal variation in heavy metals of forest soils of Dehradun
}

\author{
RAJDEO KUMAR*, SOHNI SINHA, AMIT RANJAN KUMAR, LAXMI RAWAT
}

\author{
Ecology, Climate Change and Forest Influence Division, Forest Research Institute, \\ Dehradun (Uttarakhand)-248006
}

Received: September, 2020; Revised accepted, October, 2020

\begin{abstract}
The present study was carried out to characterise the load of heavy metal in the forest soils of Dehradunduring various seasons. Surface $(0-15 \mathrm{~cm})$ and sub surfacr $(15-30 \mathrm{~cm})$ soil samples were collected from four different sites during summer, monsoon and winter seasons. The results revealed that the maximum Cadmium concentration was recorded in surface $(0-15 \mathrm{~cm})$ soils and minimum in sub-surface soils $(15-30 \mathrm{~cm})$. The Cd concentration maximum during summer followed by winter and monsoon. Similar pattern of distribution of chromium was recorded in surface soil. The Chromium content was observed in the order of winter>summer>monsoon in surface soil and summer>winter>monsoon in sub-surface soils. The concentration of Copper in surface soils varied from 3.19 to $0.52 \mathrm{mg} \mathrm{kg}^{-1}$ while in sub-surface soil, it varied between 2.25 and $0.57 \mathrm{mgkg}^{-1}$. The copper concentration was maximum during winter followed by summer and monsoon. The lead concentration was recoeded maximum at site-II and minimum at site-IV whereas, it was recorded maximum during winter and minimum during monsoon. In general, all the heavy metals were found to decrease with soil depth. The concentrations of heavy metal were quite low but their presence in sites makes them potential to increase toxicity in future owing to more environmental degradation.
\end{abstract}

Keywords: Pollution, prbanisation, heavy metals, soil, pesticide, fertilizer, industrialization

\section{INTRODUCTION}

Soil is an important component of the environment and its supports various life in the form of microorganisms, earthworms and other soil fauna and flora and exchanges air, water and minerals to stay alive and keeps on growing with time. Although it is considered as nonliving, but in true sense soil is living. Soils respire and the process of respiration is an important ecosystem activity responsible for carbon release in the form of $\mathrm{CO}_{2}$. Soils have an important role to play in various environmental amenities viz., a base for production of biomass, water buffer and filter, Natural and Historical Archive, and one of the biggest storehouses of carbon. These all ecological systems are now become essential to modern ecology. Soil pollution caused by heavy metal contamination is a rapidly rising environmental concern led by the incessant industrial growth and urbanization. The bio-accumulation of these elements in plants and animals led to their entry into the food chain (Bhagure and Mirgane, 2010). The higher amount of accumulation has been observed in the regions showing high industrial proximity compared to the non contaminated areas (Kumar et al., 2020). Heavy metals in urban soil are very useful tracers of environmental pollution. Soil pollution caused by heavy metal contamination is a rapidly rising environmental concern led by the incessant industrial growth and urbanization (Parth et al., 2011). The toxic and other ill effects rendered by heavy metal contamination in living being has caused the researchers to understand the mechanism underlying their origin and fate in the environment (Rattan et al., 2005, Saha et al., 2013). The improper hazardous waste disposal or accidental chemical releases are among the major sources of soil contamination. The different sources of heavy metals can be identified as industrial discharge and energy production, chemicals used in agricultural production, construction, chemicals used for agricultural purpose, vehicle wear, particulate emissions from vehicular exhaust, combustion of fossil fuel and airborne dust. (Sharma et al. 2006 and 2007) The improper hazardous waste disposal or accidental chemical releases are among the major sources of soil contamination. Moreover, soils serve both as the source and sink for different types of heavy metals and due to their low degradation rate, they are highly stable and persistent in the soil environment. Their adverse effects has been observed on the 
health of human and other beings residing in both aquatic and terrestrial environment. Therefore, it is the need of the hour to quantify the level of heavy metals ions in the soil. Hence, the present study was initiated to assess the seasonal variation in heavy metals of forest soils.

\section{MATERIALS AND METHODS}

'Doon Valley' is a wide bouldry valley of Uttarakhand which lies between Shivalik hills on one side and Lower Himalayas on the other side, located between river Ganga and Yamuna, at the north- western limit of Uttar Pradesh and adjoining Himanchal Pradesh state in India. The four study sites in Dehradun $\left(30^{\circ} 19^{\prime} \mathrm{N}\right.$ and $\left.78^{\circ} 02^{\prime} \mathrm{E}\right)$ were selected. The surface $(0-15 \mathrm{~cm})$ and sub-surface $(15-30 \mathrm{~cm})$ soil samples were collected from four different sites namely New forest area (site-I), Clock tower (site-II), Selaque (site-III) and Karwapani (site-IV) during summer, monsoon and winter seasons. The samples thus collected were brought to the laboratory, dried processed and analysed for heavy metals. These soil samples were extracted with DTPA extractant (Lindsay and Norwell, 1978) for Cd, $\mathrm{Cr}, \mathrm{Cu}$ and $\mathrm{Pb}$. These heavy metals in the extract were determined by atomic absorption spectrophotometer. Simple correlation coefficients were made to relate heavy metals among them selves by adopting standard procedures.

\section{RESULT AND DISCUSSIONS}

\section{Cadmium}

The cadmium concentration in surface $(0-$ $15 \mathrm{~cm})$ and sub-surface $(15-30 \mathrm{~cm})$ soils were varied from 0.02 to $0.25 \mathrm{mgkg}^{-1}$ and 0.02 to $0.13 \mathrm{mgkg}^{-1}$, respectively. The concentration of $\mathrm{Cd}$ was maximum at site-II and minimum at siteIV (Table 1). The maximum concentration of $\mathrm{Cd}$ was recorded during summer and minimum in monsoon in surface soils. On the other hand, the concentration of $\mathrm{Cd}$ in sub-surface soil was maximum during summer and more or less equal during monsoon and winter season. Since, the soils are formed from the same parent material considerable higher $\mathrm{Cd}$ content detected in these soils have resulted from external addition of $\mathrm{Cd}$ by application of sewage sludge, phosphate fertilizer, waste water and pesticides. These results are in consistent with the finding of Kumar and Maite (2015) and Singh and Singh (2017). The lower concentration of $\mathrm{Cd}$ during monsoon and winter season may be attributed to its leaching. During summer season, $\mathrm{Cd}$ is accumulated in surface soil due to its movement towards upper layers of the soil. In general, the concentration of $\mathrm{Cd}$ tended to decrease with depth and relatively higher amount of $\mathrm{Cd}$ was noted in surface soils than those of sub-surface soils.

Table 1: Status of Cadmium $\left(\mathrm{mgkg}^{-1}\right)$ in forest soils

\begin{tabular}{c|c|c|c|c|c|}
\hline Season & $\begin{array}{c}\text { Depths } \\
(\mathrm{cm})\end{array}$ & $\begin{array}{c}\text { Site- } \\
\text { I }\end{array}$ & $\begin{array}{c}\text { Site } \\
\text { ii }\end{array}$ & $\begin{array}{c}\text { Site } \\
\text { iii }\end{array}$ & $\begin{array}{c}\text { Site } \\
\text { iv }\end{array}$ \\
\hline \multirow{2}{*}{ Summer } & $0-15$ & 0.05 & 0.25 & 0.07 & 0.02 \\
& $15-30$ & 0.03 & 0.13 & 0.07 & 0.02 \\
Monsoon & $0-15$ & 0.04 & 0.11 & 0.07 & 0.03 \\
& $15-30$ & 0.04 & 0.08 & 0.04 & 0.02 \\
\multirow{2}{*}{ Winter } & $0-15$ & 0.03 & 0.12 & 0.10 & 0.04 \\
& $15-30$ & 0.02 & 0.08 & 0.07 & 0.03 \\
\hline
\end{tabular}

\section{Chromium}

The chromium content in surface soils varied from 0.16 to $1.15 \mathrm{mgkg}^{-1}$ irrespective of season. The corresponding range of $\mathrm{Cr}$ in subsurface soil was from 0.03 to $0.67 \mathrm{mgkg}^{-1}$. Among the sites, site-II contained the maximum amount of $\mathrm{Cr}$ whereas the site-III had the lowest amount of chromium (Table 2). Similar, results were reported by Kumar and Maiti (2013). The amount of $\mathrm{Cr}$ in surface soil was maximum in winter season followed by summer and monsoon. In sub-surface soil, maximum and minimum amounts of chromium were recorded during summer and monsoon season, respectively. This may be due to accumulation of $\mathrm{Cr}$ in surface soil during summer season. The minimum amount of $\mathrm{Cr}$ during monsoon owing to loss from the surface soil due to leaching. The discarded plastic material, lead chromium batteries, empty paints container, coloured polythene bags act as the significant sources of chromium in soil. In general, there was a declining trend in accumulation of chromium in soil and relatively higher concentration of $\mathrm{Cr}$ was recorded in surface soils than sub-surface soils (Saha et al. 2013). 
Table 2: Status of Chromium $\left(\mathrm{mgkg}^{-1}\right)$ in forest soils

\begin{tabular}{c|c|c|c|c|c|}
\hline Season & $\begin{array}{c}\text { Depths } \\
(\mathrm{cm})\end{array}$ & Site-I & $\begin{array}{c}\text { Site- } \\
\text { II }\end{array}$ & $\begin{array}{c}\text { Site- } \\
\text { III }\end{array}$ & $\begin{array}{c}\text { Site- } \\
\text { IV }\end{array}$ \\
\hline \multirow{2}{*}{ Summer } & $0-15$ & 0.71 & 0.83 & 0.41 & 0.07 \\
& $15-30$ & 0.66 & 0.67 & 0.07 & 0.06 \\
Monsoon & $0-15$ & 0.16 & 0.60 & 0.03 & 0.09 \\
& $15-30$ & 0.09 & 0.11 & 0.03 & 0.04 \\
Winter & $0-15$ & 0.29 & 1.15 & 0.45 & 0.18 \\
& $15-30$ & 0.18 & 0.51 & 0.05 & 0.11 \\
\hline
\end{tabular}

\section{Copper}

The concentration of copper in surface soils varied from comparison of $\mathrm{Cu}$ concentration in surface soil was varied from 0.52 to 3.19 $\mathrm{mgkg}^{-1}$ while in sub-surface soils it varied from 0.57 to $2.25 \mathrm{mgkg}^{-1}$. Similar results were reported by Singh and Singh (2017) and Bhagure and Mirgane (2010). The copper content in these forest soils is hugely affected by weathering of biotite, plagioclase and orthoclase (Parth et al., 2011). Copper in soils gets strongly attached with minerals and organic matter. Hence, the amount of copper in surface soils was higher than sub-surface soils. In both surface and sub-surface soils, the copper content was recorded maximum at soil-II and minimum at site-IV (table iii). The amount of copper in surface and sub-surface soils was maximum during winter and minimum $n$ monsoon. This might be due to the ruboff effect that is capable of removing heavy metals in general and copper in particular from the land. The effects of rainfall during monsoon may facilitate the leaching of the soil and contributes to the dilution of soil solution during the wet season.

Table 3: Status of Copper $\left(\mathrm{mgkg}^{-1}\right)$ in forest soils

\begin{tabular}{l|c|c|c|c|c|}
\hline Season & $\begin{array}{c}\text { Depths } \\
(\mathrm{cm})\end{array}$ & Site-I & $\begin{array}{c}\text { Site- } \\
\text { II }\end{array}$ & $\begin{array}{c}\text { Site- } \\
\text { III }\end{array}$ & $\begin{array}{c}\text { Site- } \\
\text { IV }\end{array}$ \\
\hline \multirow{2}{*}{ Summer } & $0-15$ & 1.30 & 2.39 & 1.76 & 0.61 \\
& $15-30$ & 1.13 & 1.38 & 1.15 & 0.57 \\
Monsoon & $0-15$ & 1.09 & 1.82 & 1.02 & 0.52 \\
& $15-30$ & 0.95 & 0.87 & 0.77 & 0.59 \\
\multirow{2}{*}{ Winter } & $0-15$ & 1.37 & 3.19 & 1.64 & 0.74 \\
& $15-30$ & 1.23 & 2.25 & 0.99 & 0.81 \\
\hline
\end{tabular}

\section{Lead}

The surface and sub-surface soils had $3.93 \mathrm{mgkg}^{-1}$ lead (range 0.87 to $3.93 \mathrm{mgkg}^{-1}$ ) and $2.60 \mathrm{mgkg}^{-1}$ (range 0.64 to $2.60 \mathrm{mgkg}^{-1}$ ), respectively. The concentration of lead was maximum at site-II and minimum at site-IV in both the depths i.e. $0-15$ and $15-30 \mathrm{~cm}$ as per table-iv. Saha et al. (2013) and Rajindiranet al. (2015) also reported similar results in polluted soils of India. The soils collected from both the depths $(0-15$ and $15-30 \mathrm{~cm})$ had maximum and minimum concentrations during winter and monsoon, respectively. Increased lead levels may be associated with anthropogenic activities such as dumping of chemical/ industrial wasyte material (Parth et al., 2011). Moreover, evaporation is more intense in dry season thus causes soil solution more concentrated in terms of heavy metals. Transport near the forest sites may be one reason but the concentration is negligible but their presence in sites makes them potential to increase toxicity in future owing to more environmental degradation. Generally, lead concentration decreased with depths irrespective of sites and season.

Table 4: Status of lead $\left(\mathrm{mgkg}^{-1}\right)$ in forest soils

\begin{tabular}{c|c|c|c|c|c|}
\hline Season & $\begin{array}{c}\text { Depths } \\
(\mathrm{cm})\end{array}$ & Site-I & $\begin{array}{c}\text { Site- } \\
\text { II }\end{array}$ & $\begin{array}{c}\text { Site- } \\
\text { III }\end{array}$ & $\begin{array}{c}\text { Site- } \\
\text { IV }\end{array}$ \\
\hline \multirow{2}{*}{ Summer } & $0-15$ & 1.20 & 1.99 & 1.98 & 1.45 \\
& $15-30$ & 0.95 & 1.40 & 0.96 & 0.97 \\
Monsoon & $0-15$ & 0.99 & 0.98 & 1.84 & 0.87 \\
& $15-30$ & 0.87 & 1.02 & 0.94 & 0.64 \\
Winter & $0-15$ & 1.66 & 3.93 & 1.54 & 1.11 \\
& $15-30$ & 0.97 & 2.60 & 1.24 & 1.09 \\
\hline
\end{tabular}

\section{Relationship among heavy metals}

Pearson's correlation coefficient matrix was worked out for heavy metals in surface and sub-surface soils (Table 5). Results of correlation matrix revealed that chromium had positive correlation with $\mathrm{Pb}$ and $\mathrm{Cu}$ at 0.01 level whereas, $\mathrm{Pb}$ had positive correlation with $\mathrm{Cd}$ at 0.05 level and $\mathrm{Cr}$ and $\mathrm{Cu}$ at 0.01 level in surface soil. While in sub surface soil, it showed positive relationship with $\mathrm{Cd}, \mathrm{Cu}$ and $\mathrm{Cu}$ at 0.05 level. 
Table 5: Correlation matrix of heavy metals in soil of both depths

\begin{tabular}{|c|c|c|c|c|c|c|c|c|}
\hline \multicolumn{5}{|c|}{ Depth $(0-15 \mathrm{~cm})$} & \multicolumn{4}{|c|}{ Depth $(15-30 \mathrm{~cm})$} \\
\hline Parameters & $\mathrm{Cd}$ & $\mathrm{Cr}$ & $\mathrm{Cu}$ & $\mathrm{Pb}$ & $\mathrm{Cd}$ & $\mathrm{Cr}$ & $\mathrm{Cu}$ & $\mathrm{Pb}$ \\
\hline $\mathrm{Cd}$ & 1.00 & & & & 1.00 & & & \\
\hline $\mathrm{Cr}$ & $0.54^{\star *}$ & 1.00 & & & 0.32 & 1.00 & & \\
\hline $\mathrm{Cu}$ & $0.60^{* *}$ & $0.81^{\star \star}$ & 1.00 & & $0.51^{*}$ & $0.50^{*}$ & 1.00 & \\
\hline $\mathrm{Pb}$ & $0.50^{*}$ & $0.58^{\star \star}$ & $0.72^{* *}$ & 1.00 & $0.51^{*}$ & $0.44^{*}$ & $0.86^{\star *}$ & 1.00 \\
\hline $\begin{array}{l}{ }^{*} \text {. significant at } t l \\
{ }^{* \star} \text {. significant at }\end{array}$ & $\begin{array}{l}\text { level (2 } \\
1 \text { level ( }\end{array}$ & $\begin{array}{l}\text { ed) } \\
\text { iled) }\end{array}$ & & & & & & \\
\hline
\end{tabular}

The copper content in surface and sub surface soil showed significant and positive relation ship with Cadminum and chromim content.Based on findings of present study, it could be inferred that the forest soils of

\section{REFERENCES}

Bhagure, G.R. and Mirgane, S.R. (2010) Heavy metal concentrations in ground waters and soils of Thane Region of Maharashtra, India.Environmental monitoring and assessment 173:643-652.

Kumar A. and Maiti, S.K. (2013) Availability of chromium, nickel and other associated heavy metals of ultramafic and serpentine soil/ rock and in plants. International Journal of Emerging Technology and Advanced Engineering 3(2):256-273.

Kumar A. and Maiti, S.K. (2015) Assessment of potentially toxic heavy metal contamination in agricultural fields, sediment, and water from an abandoned chromite-asbestos mine waste of Roro hill, Chaibasa, India. Environment Earth Science 74:2617-2633.

Kumar, D., Singh, S.K, and Mann, S. (2020) Assessment of sewage water quality and its effect on soil properties of siuth eastern cities of Haryana. Annals of Plant and Soil Research 22(2):182-185.

Lindsay, W.L. and Norwell, W.A. (1978) Development of DTPA soil test for Zinc, Iron, Manganese and Copper.Soil Science Society of America Journal 42:421-428.

Parth, V., Murthy, N.N. and Saxena, P.R. (2011) Assessment of heavy metal contamination in soil around hazardous waste disposal sites in Hyderabad City (India): Natural and Anthropogenic Implications. Journal of Environmental Research and Management 2 (2):27-34.
Dehradun werequite low in heavy metals. In general heavy metals tended to decline with depth. There was a higher concentration of heavy metals in surface soil in summer.

Rajindiran, S., Dotaniya, M.L., Vassanda, C.M., Panwar, N.R. and Saha, J.K. (2015) Heavy metal polluted soils in India: status and countermeasures. JNKVV ResearchJournal (J.N. Agriculture University, Jabalpur) 49(3):320-337.

Rattan, R.K., Dass, S.P., Chhonkar, P.K., Suribabu, K. and Singh, A.K. (2005) Long term impact of irrigation with sewage effluents on heavy metal content in soil, Crop and groundwater, Agriculture Ecosystem and Environment 109:310322.

Saha J.K., Panwar, N. and Singh M.V. (2013) Risk Assessment of heavy metals in soil of a susceptible Agro-ecological system amended with municipal solid waste compost. Journal of the Indian Society of Soil Science 61(1):15-22.

Sharma, R.K., Agrawal, M., Marshall, F.M. (2006) Heavy metals contamination in vegetables grown in wastewater irrigated areas of Varanasi, India. Bulletin of Environmental Contamination and Toxicology 77:311-318.

Sharma, R.K., Agrawal, M., Marshall, F.M. (2007) Heavy metals contamination of soil and vegetables in suburban areas of Varanasi, India. Ecotoxicology and Environmental Safety 66:258-266.

Singh, V. and Singh, H (2017) Status of nutrients and heavy metals in soils and vegetable crops irrigated with sewage water. Annals of Plant and Soil Research 19(1):7-11. 